\title{
The Use of Recycled Objects as English Teaching Media for Young Learners (A Theoretical Review)
}

\author{
Fiorentina Dewantari \\ Ganesha University of Education, Indonesia \\ fiodewantari24@gmail.com
}

\begin{abstract}
This study is a library study about the use of recycled objects as teaching media. The use of teaching media is one of the supporting components in teaching. Especially for young learners, the choice of media is an important thing to support them in learning English. Several media can be selected by teachers to be given to young learners. One of them is disposable media in the form of recycled objects that use objects around us. The teacher must be able to create the media to make the learning process more fun and informative. Through recycled objects as teaching media, young learners can learn how to use objects around them without having to use expensive media for learning. Therefore, this article was aimed at sharing the use of recycled objects as English teaching media for young learners. So that, young learners are expected to be motivated in the learning process.
\end{abstract}

Keywords: recycled objects, teaching media, young learner

\section{INTRODUCTION}

Teaching media is a component that has an important influence on the learning process. The media becomes an intermediary for how the information is conveyed to students (Kozma, 1991). Through the media, a teacher can also communicate and interact with students in the learning process. This will affect the learning process of students in understanding the material conveyed by the teacher through teaching media. Besides that, teaching media has an important role as the supporting tool for students in learning (Sukmahidayanti, 2015). Teaching media facilitates teachers in teaching and students in understanding the material. Kozma (1991) stated that with the existence of teaching media, the teaching and learning process will be more effective.

An effective and fun learning environment are also the influence of the use of teaching media. The teacher's creation in providing teaching media will be able to create a more attractive learning atmosphere in the classroom (Sukmahidayanti, 2015). Especially for young learners who are at the golden age to learn many things easily. The age of young learners is in the range for active learning period (Sukarno, 2012). The curiosity, creativity, and critical thinking of the young learners began to develop. It will make the range age of young learners will be easier in learning English. English is a foreign language in Indonesia so that students will get another challenge to learn English. Therefore, a teacher must be able to handle young learners and know how to teach English for young learners. The choice of teaching media in teaching young learners must be considered by a teacher. Teachers should consider the appropriate media based 
on the age of young learners (Fitrawati, 2013). Besides that, Sukarno (2012) stated that the influence of teaching media must be considered, such as the effectiveness of the media in delivering material. This will have an impact on the process and the results of learning for young learners.

Various media can be used to teach young learners. For disposable media, it can be used recycled objects. The disposable object can be made from materials around people which can be recycled into teaching media. In addition, the use of recycled objects as teaching media will help people to save the earth (Nuss et al., 2012). Usually, materials such as plastic and paper will be more easily recycled into teaching media. Through the recycled media, the teacher has to be more creative and able to make good media of existing materials. So that the learning process will be more fun for young learners.

For young learners, learning and playing are still closely related to them so that teachers must create teaching media that are appropriate to their circumstances so that they do not get bored when learning (Sukarno, 2012). This will have an impact on the motivation of young learners in learning. Sukarno (2012) also stated if young learners are provided with a fun and effective learning process through new media for them, they will be more motivated to learn. They will also realize and learn that waste objects around them can be used as teaching media without having to spend a lot of money to make teaching media. By using recycled objects as a teaching media, the learning process of young learners will be more meaningful and effective.

There are three previous studies that are used as empirical reviews related to the topic of this article. Uyanik et al. (2011) did research about the exploration of waste materials in early childhood education. The aim of this study was to target children who cannot express language orally and presents examples of activities that can be used by students in order to express language through recycled materials. Recycled material made students be able to get lots of ideas and practice thinking skills. Some of the recycled materials used are boxes, plastic, bottles, cloth, paper, reels, beads, nutshells, tree shells, and leaves. This study found the result that the use of waste materials had positive impacts on students where students could learn how to recycle materials and use them properly so that this activity would improve students' creative thinking then confidence in expressing spoken language.

Sukmahidayanti (2015) conducted research to analyze the utilization of instructional media in teaching English to young learners. The purpose of this study was to describe the preparation of teachers before starting to teach and how teachers use the media to teach young learners. Many teachers in Indonesia had problems in using the media for teaching due to the limited support facilities provided by schools. One of the factors causing was the high cost of supplying supporting facilities. So that, in using teaching media teachers faced problems in media selection, timing, and negative perspectives that arise about instructional media. The result of this research was the preparation and utilization of the media still lack in Indonesia.

Puspitarini \& Hanif (2019) conducted research related to the use of teaching media to increase learning motivation in elementary school. The purpose of this research was to find out how the use of innovative media in the classroom and the influence of teaching media on students' motivation. Based on the interview obtained, the students felt more motivated to learn using media other 
than books. Students also seem bored if the teacher teaches using lecture techniques so that their motivation decreases in learning. The result of this research found that students are more motivated to learn by using innovative media because this will prevent them from being bored in learning.

Based on the previous studies stated above, it can be said that the use of recycled objects as teaching media is very effective and innovative for young learners. As we know that recycled objects are very easy to find around us and the use of teaching media will motivate students in learning process.

\section{METHOD}

The method used in this study is a library study. The library study is a data collection method carried out in literary form from various sources such as books and articles to support this study. The step of collecting data using this study is also called a literature study because the process is through reading, listening, or processing activities based on literature to support the study. Ary et al. (2009) said that the process of analyzing a document or literature begins with a researcher's question about something and answers it by analyzing it through literature. Furthermore, the result of the question is interpreted into a description and explanation. Looking at the data collection process of the library study, this study begins with the problem of how recycled objects are used as a teaching medium for young learners. Furthermore, the description is obtained through an analysis of literature or documents related to this study.

\section{FINDINGS AND DISCUSSIONS}

Young learners are children aged 7-11 years in general (Fitrawati, 2013). The period of young learners is a period where they have just learned many things. A strong sense of curiosity makes young learners be active. Besides that, young learners still prefer to learn with a lot of action (Sukarno, 2012). They still like to learn while playing. So that the various components of teaching young learners with students will be different based on their needs and circumstances. This is because young learners are students who are still in the period of developing their abilities and skills. Therefore, the various teaching components must be selected based on the young learner's character (Sukarno, 2012). Young learners are very easily bored with studying. As a teacher, this must be anticipated by creating a learning environment and learning strategy that is more fun and interesting. So that, it will make the material that presented to young learners is easier to understand and they are more motivated to learn. Various teaching factors such as the learning environment, teaching strategies, and teaching media must be adjusted to the characteristics of the learner so that the learning process will be effective.

Preeti (2014) stated that teaching media is a thing that aims to deliver information to the audience. In addition, the purpose of the media is also to provide knowledge to educate people. The teaching media is representative of a wide range of knowledge to make students can reach information contained in the media (Preeti, 2014). Teaching media is a component in teaching that must be paid attention by the teacher. The teacher has an important role in choosing and determining the teaching media according to the material and the situation of the students (Sukmahidayanti, 2015). So that, it makes the function of the media used is beneficial to the students and is not just a media. Almost every subject can use 
the same media, including English. The teaching media for English can be the same as other subjects. But the media will be better if it can deliver the information properly and can motivate students in learning. The support and role of the media will influence the learning system between teachers and students on the effectiveness of the material presented. Therefore, it can be said that teaching media is an important component used by teachers to convey material to students. The selection and determination of teaching media must be adjusted to the material and the conditions of students so that the media becomes effective in the learning process. The teacher also has an important role in determining the teaching media to be used in teaching young learners and how to create them. Various media can be created simply for teaching including utilizing something in the environment that is easily found and can be recycled into teaching media.

Waste material is a disposable object that is discarded when it is not used. However, some of the waste materials can be recycled into items that are more useful to become recycled objects. Recycled objects are items that have been updated from waste materials to things that can be used (Nuss et al., 2012). Some of the waste materials that can be recycled into various creations are paper, plastic, boxes and cans. Various kinds of product creations can be made from waste materials, including teaching media (Uyanik et al., 2011). Recycled objects as teaching media can be used for making day spinner from paper. Where the spinner is made like a windmill from paper by filling in each side of the name of the days which can be used with singing activities and then answer the questions based on the spinner. For example, the teacher invites students to sing the name of the day while showing it on the spinner. After stopping, the teacher can appoint students one by one to spin the spinner, then the teacher asks questions according to the arrow shown on the spinner. Take for example if the arrow points to Tuesday, the teacher can ask the student what day is before Tuesday or the day after Tuesday. Besides the name of the day, this spinner can also be created by filling in the names of objects, animals, and others with different learning activities. It must also be adjusted to the teaching topic and situation. Besides that, there are still many more recycled objects creation that can be used as teaching media. So it can be stated that recycled objects are disposable media that use waste material for more useful things. Recycled media can be created into various kinds of objects including teaching media to makes the innovative media in teaching.

\section{CONCLUSIONS}

The conclusion of this article is recycled objects can be used as English teaching media by the teacher. As we know that, learning English as a foreign language for young learners still needs to be considered in many aspects such as the choice of teaching media. Recycled objects categorize as disposable media which can be used by young learners to learn English. Recycled objects are very easy to find around us and the creation of recycled media should be considered by the teacher. The teacher should be able to make the teaching media from recycled objects to be more effective teaching media. So that, the material delivered will be more understand and the atmosphere of the learning process will be more fun. Therefore, recycled objects can be used as English teaching media for young learners. 


\section{REFERENCES}

Ary, D., Jacobs, L. C., Sorensen, C., \& Razavieh, A. (2009). Introduction to Research in Education (8th editio, Vol. 3, Issue 2). Wadsworth Publishing. http://repositorio.unan.edu.ni/2986/1/5624.pdf

Fitrawati. (2013). Teaching English for Young Learners "How They Learn and Pedagogigal Implication ". Pedagogi, 13(2), 62-66.

Kozma, R. B. (1991). Learning with media. Review of Educational Research, 61(2), 179. https://doi.org/10.2307/1170534

Nuss, P., Bringezu, S., \& Gardner, K. H. (2012). Waste-to-Materials: The Longterm Option. Green Energy and Technology, 55, 1-26. https://doi.org/10.1007/978-1-4471-2306-4_1

Preeti. (2014). Education and role of media in education system. International Journal of Scientific Engineering and Research, 2(3), 174-175. http://www.ijser.in/archives/v2i3/SjlwMTMxNTg=.pdf

Puspitarini, Y. D., \& Hanif, M. (2019). Using Learning Media to Increase Learning Motivation in Elementary School. Anatolian Journal of Education, 4(2), 5360. https://doi.org/10.29333/aje.2019.426a

Sukarno. (2012). Teaching English to Young Learners and Factors to Consider in DesigningThe Materials. Jurnal Ekonomi Dan Pendidikan, 5(1), 57-73. https://doi.org/10.21831/jep.v5i1.603

Sukmahidayanti, T. (2015). The utilization of instructional media in teaching english to young learners. Journal of English and Education, 2015(2), 90100.

Uyanik, O., Inal, G., Calisandemir, F., Can-Yasar, M., \& Kandir, A. (2011). New Explorations with Waste Materials in Early Childhood Education. Online Submission, 1, 111-118. 